\title{
A HOT-WIRE ENGINE TO PRODUCE PERIODIC GROOVES ON AN ICE SURFACE
}

\author{
By T. M. Tobin and K. Itagaki \\ (U.S. Army Cold Regions Research and Engineering Laboratory, Hanover, New Hampshire \\ o3755, U.S.A.)
}

\begin{abstract}
A strain-free grooving method has been developed for surface self-diffusion studies of ice. This method utilizes a hot-wire grooving engine and is capable of obtaining a uniform spacing between grooves ranging from $\mathrm{I} 5.9 \mu \mathrm{m}$ to $159 \mu \mathrm{m}$ in increments of $15.9 \mu \mathrm{m}$.

RÉsumé. Un appareil à fil chaud pour produire des réseaux gravés réguliers à la surface de la glace. On a mis au point une méthode pour graver des fines rainures dans la glace sans lui faire subir d'efforts, en vue d'études sur l'autodiffusion de surface dans la glace. Cette méthode utilise un appareil de gravure à fil chaud et permet d'obtenir un espacement régulier entre les rainures variant de ${ }_{1} 5,9 \mu \mathrm{m}$ à $\mathrm{I} 59 \mu \mathrm{m}$ par paliers de $15,9 \mu \mathrm{m}$.

Zusammenfassung. Ein Heizdraht-Gerät zur Herstellung periodischer Rillen auf einer Eisoberfläche. Eine Methode zur spannungsfreien Riefelung für Studien der Eigendiffusion an Oberflächen von Eis wurde entwickelt. Die Methode verwendet ein Heizdraht-Riefelgerät, das Rillen mit gleichmässigen Abständen von $19.9 \mu \mathrm{m}$ bis $159 \mu \mathrm{m}$ in Schritten von ${ }_{1} 5.9 \mu \mathrm{m}$ zu erzeugen gestattet.
\end{abstract}

\section{INTRODUCTION}

Surface self-diffusion studies by scratch decay techniques have been conducted on metals for the past few years (Mullins, I959; Blakely and Mykura, I961, I962; King and Mullins, r962; Blakely, 1963). This method is presently being used by the authors to investigate the surface and interface structures of ice and their relationship to the problem of ice adhesion. A strain-free grooving method is essential because conventional mechanical methods which introduce large numbers of dislocations can alter the surface properties.

Recently a grooving engine has been built to make uniformly spaced grooves on an ice surface. The hot-wire grooving engine derives its name from the simple diffraction grating engine. The engine utilizes a hot wire to melt the grooves instead of a mechanical technique in order to obtain strain-free surfaces with a minimum of dislocations. The grooves are made by using a fine $(c .30 \mu \mathrm{m})$ resistance wire to melt the grooves onto the surface at the desired spacing. By means of a cog wheel which advances the ice sample, one can obtain a spacing between grooves ranging from ${ }_{5} 5.9 \mu \mathrm{m}$ to ${ }_{1} 59 \mu \mathrm{m}$ in steps of ${ }_{1} 5.9 \mu \mathrm{m}$.

\section{Apparatus}

The grooving engine is shown schematically in Figure I. The principal components are the 40 r.p.m. motor, lifting cam, advancing cam, cog wheel, melting wire, vacuum plate, and Unislide (linear screw-advancing mechanism). Other components in Figure I include a $40 \times$ microscope, aluminum base, adjustable stop, two soft-plate springs and a clear plastic platform with three leveling screws. The adjustable stop is used to vary the groove spacing by changing the number of notches being advanced on the cog wheel. The leveling screws threaded into the Lucite platform allow one to adjust the height and parallelism of the electrically heated melting wire, so that the wire barely makes contact with the ice sample. The leveling screws are countersunk into an aluminum base so that the platform does not shift during the operation. The $40 \times$ microscope is mounted directly over the fine wire to provide direct observation of the entire grooving operation. All component parts of the grooving engine are mounted on an aluminum base $(45.7 \mathrm{~cm} \times 25.4 \mathrm{~cm} \times \mathrm{r} .6 \mathrm{~cm})$ in order to minimize the effect of mechanical vibrations on the grooving process. 
The grooving engine operates as follows (see Fig. I): The ice sample $(5 \mathrm{~cm} \times 3 \mathrm{~cm} \times \mathrm{I} \mathrm{cm})$ is frozen to a microscope slide $(7.5 \mathrm{~cm} \times 5 \mathrm{~cm})$ which is then mounted on the vacuum plate. This vacuum plate is mounted on the traveling stage of a Unislide. The screw (20 threads/ $2.54 \mathrm{~cm}$ ) of the Unislide is advanced by the 8o-toothed $\operatorname{cog}$ wheel. The $\mathrm{cog}$ wheel is driven by an advancing cam and a linkage connected to the shaft of the 40 r.p.m. motor. Also mounted to the shaft of the motor is a lifting cam which lags the advancing cam in phase by $90^{\circ}$. The lifting cam raises and lowers the Lucite platform on which the grooving wire is attached. This fine wire, stretched by two soft-plate springs, makes contact with the surface of the ice sample for about $\frac{2}{3}$ of the cycle of operation. During this time the grooves or furrows are created on the surface. The platform is lifted during the remainder of the cycle and the ice sample is advanced by the advancing cam and cog wheel. The advance can be adjusted so that the spacing between grooves can range from ${ }_{1} 5.9 \mu \mathrm{m}$ to ${ }_{1} 59 \mu \mathrm{m}$ in $15.9 \mu \mathrm{m}$. Since both the advancing and lifting cams are attached to the shaft of the 40 r.p.m. motor, one grooving cycle is completed in $1.5 \mathrm{~s}$.

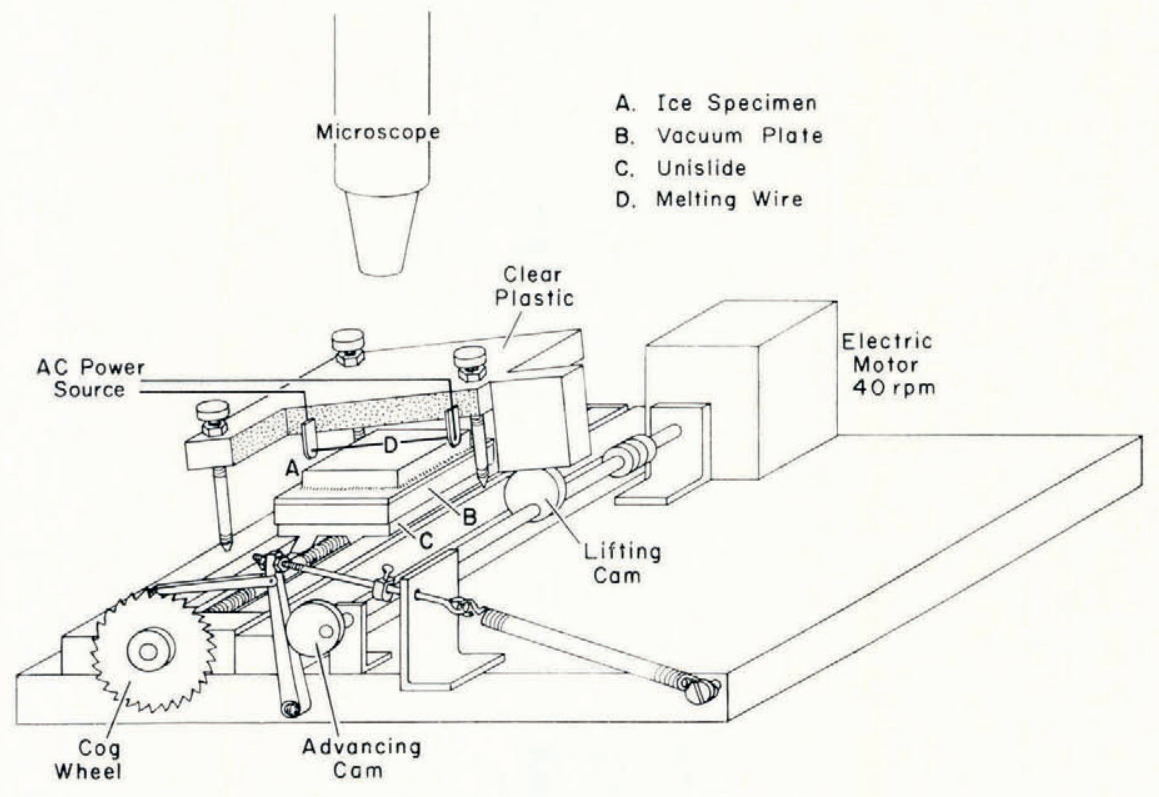

Fig. I Diagram of the hot-wire grooving engine.

\section{SAMPLE PREPARATION AND ADJUSTMENT}

After the ice samples $(5 \mathrm{~cm} \times 3 \mathrm{~cm} \times \mathrm{I} \mathrm{cm})$ were cut with a band saw to the desired crystallographic orientation, Itagaki's freeze-tap technique (Tobin and Itagaki, 1970) was used to obtain a strain-free flat surface on the ice sample. The etch pit density of the surface thus formed was approximately the same as the bulk dislocation density obtained by the X-ray topographic method, indicating that the method produced strain-free flat surfaces.

During the actual process of creating grooves on the surface of an ice sample, two adjustments were critical. First, by means of the leveling screws threaded into the Lucite platform, the grooving wire had to be made parallel to the surface of the ice sample. If this condition had not been met, uniform grooves would not have been formed across the sample surface. Secondly, the current in the melting wire had to be adjusted by a transformer so that the grooves formed were about the same diameter as the grooving wire itself. The setting of the 


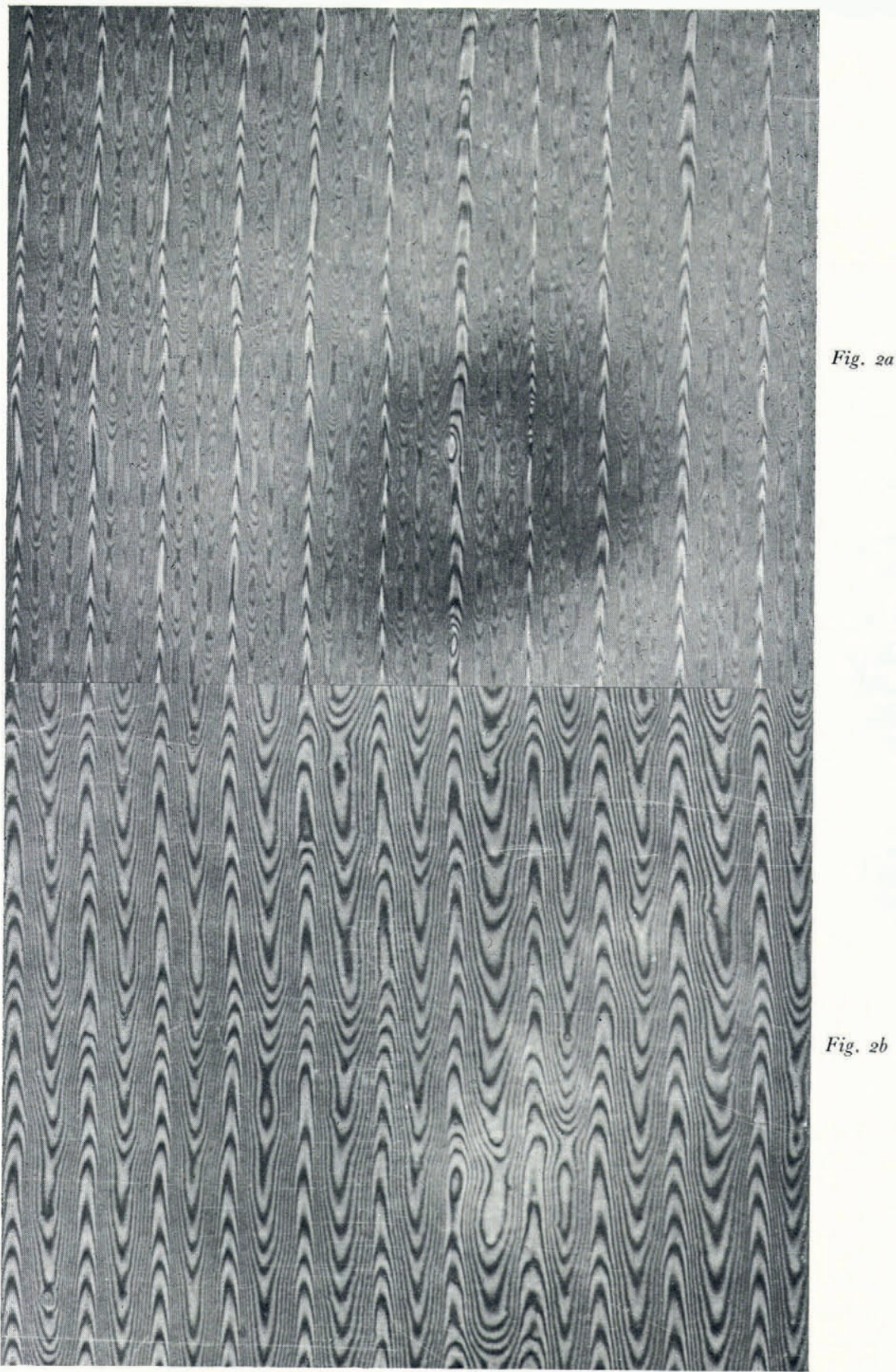

Fig. 2. (a) Interferogram of an ice surface immediately after grosve formation, $T=-10^{\circ} \mathrm{C}$. The groove spacing is $80 \mu \mathrm{m}$. (b) Interferogram of the same area after fo'r hours, $T=-10^{\circ} \mathrm{C}$. 
current adjustment in the grooving wire also had to be sufficient to prevent the wire from refreezing to the top of the ice sample.

\section{Results AND DISGUSSION}

The cross-sectional shape of the grooves produced by this engine immediately after the groove formation as revealed by the interferogram shown in Figure 2 (a) contains a considerable number of higher harmonic components. The higher harmonic components, however, decay rapidly and an almost pure sinusoidal wave is left after four hours as shown in Figure 2 (b).

There are some indications that the small amount of water melted by the hot wire is displaced to one side, however, most of the molten water seems to adhere to the wire and evaporate when it is lifted.

The present grooving engine is being employed successfully in surface self-diffusion studies of ice by scratch decay techniques results of which will be published later. The chief advantages that the grooving engine has over other grooving or furrowing techniques are the high degree of uniformity in the spacing between grooves and the depth of the grooves themselves. Strain-free grooving is another major advantage. No additional etch pits developed during the groove decay observation, indicating that this technique does not introduce dislocations. Considerable differences in measured self-diffusion features are expected compared with the conventional mechanical method which would introduce an alley with extremely high dislocation density along the groove.

One small problem existed, namely, the occasional vibration of the wire which caused slight irregularities in the groove spacing. Hopefully, by reshaping the lifting cam this problem can be minimized.

Unlike the photoetching method (Maiya and Blakely, I965, I967) widely used on metals, but not applicable to ice, the operation is very simple and inexpensive. No special chemicals or photographic equipment is required. Although this technique is not applicable to most materials, it is the most suitable method for ice.

MS. received 29 December 1969 and in revised form 4 June 1970

\section{REFERENCES}

Blakely, J. M. 1963. Surface diffusion. New York, Macmillan Co. (Progress in Materials Science, Vol. 10.)

Blakely, J. M., and Mykura, H. 1961. Surface self-diffusion measurements on nickel by the mass transfer method. Acta Metallurgica, Vol. 9, No. I, p. 23-31.

Blakely, J. M., and Mykura, H. 1962. Surface self-diffusion and surface energy measurements on platinum by the multiple scratch method. Acta Metallurgica, Vol. io, No. 5, p. 565-72.

King, R. T., and Mullins, W. W. 1962. Theory of decay of a surface scratch to flatness. Acta Metallurgica, Vol. io, No. 6, p. 6oi-o6.

Maiya, P. S., and Blakely, J. M. 1965. A technique for study of mass transport mechanisms at crystal surfaces. Applied Physics Letters, Vol. 7, No. 3, p. 6o-62.

Maiya, P. S., and Blakely, J. M. 1967. Surface self-diffusion and surface energy of nickel. Fournal of Applied Physics, Vol. 38, No. 2, p. 698-704.

Mullins, W. W. 1959. Flattening of a nearly plane solid surface due to capillarity. Fournal of Applied Physics, Vol. 30 , No. I, p. $77-83$.

Tobin, T. M., and Itagaki, K. 1970. Instruments and methods. A technique for producing strain-free flat surfaces on single crystals of ice. Fournal of Glaciology, Vol. 9, No. 57, p. 385-90. 